\title{
Jacek Leociak, Spojrzenia na warszawskie getto, Warszawa: Dom Spotkań z Historią, 2011, 268 s.
}

Najnowsza książka Jacka Leociaka Spojrzenia na warszawskie getto składa się z sześciu około pięćdziesięciostronicowych zeszytów. Każdy z nich przedstawia jedną z ulic warszawskiego Muranowa, które w okresie międzywojennym były zamieszkane w większości przez Żydów, a po 16 listopada 1940 r. znalazły się w obrębie ostatecznie wówczas zamkniętego getta. Każdy zeszyt składający się na Spojrzenia... podzielony został na trzy części: „historię”, „czasy getta” oraz „epilog”. Wszystkie części książki zostały wzbogacone w mapy topograficzne, zdjęcia współczesne i archiwalne (w sumie w książce wykorzystano blisko 150 fotografii, między innymi z Żydowskiego Instytutu Historycznego, Instytutu Sztuki PAN, Archiwum Yad Vashem, Ghetto Fighter's House Museum w Izraelu, Bundesarchiv w Koblencji, United States Holocaust Memorial Museum w Waszyngtonie) oraz obszerny materiał źródłowy: relacje przedwojenne, świadectwa spisywane w czasie wojny, wspomnienia wydane po latach, wycinki z prasy oraz cytaty z dokumentów urzędowych.

Oś książki stanowi sześć ulic warszawskiego Muranowa: Krochmalna, Leszno, Karmelicka, Nowolipie, Miła i Stawki. Zostały one dobrane i ułożone w taki sposób, by pokazać, jak zmieniało się oblicze miasta, przekrój demograficzny i skład narodowościowy jego mieszkańców w ciągu ostatniego stulecia. Leociak odtwarza przedwojenny klimat miejsc, koncentrując się na przedstawieniu ich losu w kolejnych etapach istnienia getta. Interesują go zwłaszcza tereny, które wiosną $1943 \mathrm{r}$. niemal całkowicie zostały zrównane z ziemią i miały zniknąć z mapy Warszawy, po wojnie zaś zaludniły się innymi mieszkańcami, zasadniczo zmieniły swój charakter i wygląd, niekiedy także bieg oraz nazwę. „Wojna unicestwiła ulicę Nowolipie bezpowrotnie - czytamy. - Nie ma domów, podwórek, zaułków, wśród których żyli dawni mieszkańcy Nowolipia. Tamta ulica zeszła pod ziemię. Jej resztki tkwią w nasypach gruzowych, na których postawiono punktowce, galeriowce i klatkowce socrealistycznego Muranowa” (Nowolipie, s. 38).

Jacek Leociak stawia sobie za cel przede wszystkim pobudzenie refleksji o przeszłości i zachęcenie czytelników do pamiętania, nie zaś odtworzenie minionych wydarzeń: „Ta książka nie jest historią getta warszawskiego” - deklaruje w pierwszym zdaniu wprowadzenia. Leociak koncentruje się na wartości pamięci - przeżycia poznawczego, którego doświadczamy w konfrontacji ze śladami przeszłości. Bliska jest mu koncepcja francuskiego historyka Pierre’a Nory, który twierdzi, że pamięć nie zaistnieje samodzielnie i bez wysiłku, lecz trzeba ją świadomie pobudzać, podtrzymywać, utrwalać i przekazywać. Takiej właśnie roli podjął się autor Spojrzeń...: „Chciałbym zachęcić do nowego spojrzenia na miejsca dobrze znane 
współczesnym warszawiakom [...]. Chodzi o nowe widzenie Warszawy” (Krochmalna, s. 4). W mojej opinii zamysł autora, by odkryć dawną, przysypaną grubą warstwą gruzów, zamkniętą skorupami asfaltu, nieistniejącą w potocznej pamięci społecznej tkankę miasta, został spełniony. Przynajmniej częściowo, ponieważ zdolność zobaczenia tego, co nie istnieje fizycznie, jest bardzo indywidualna - zależy od naszej wewnętrznej gotowości oraz siły wyobraźni. Doskonałą pożywkę dla niej stanowią chętnie przytaczane przez Leociaka wypowiedzi, wspomnienia, fragmenty pamiętników dawnych mieszkańców, a także liczne fotografie nieistniejących dziś miejsc.

Dom Spotkań z Historią, wydawca książki, zorganizował dla warszawiaków kilka spacerów po opisywanych przez Leociaka ulicach. Będąc przewodniczką niektórych z nich, miałam okazję obserwować reakcje uczestników. Stappaniu po zmurszałych schodach kamienicy przy Chłodnej, słuchaniu echa w zwilgotniałym i pachnącym przeszłością podwórku na rogu Krochmalnej i Żelaznej, patrzeniu na burzony dom przy ul. Waliców towarzyszyły zdziwienie i niedowierzanie, rodzaj żałobnego smutku i zadumy, niepokój, jaki niekiedy odczuwamy, będąc sami na cmentarzu - jedyni żywi wśród tysięcy umarłych. Niezwykłe wrażenie zrobiła wędrówka po wyludnionej w majowe niedzielne przedpołudnie Karmelickiej, która przed wojną aż tętniła życiem: słychać było nawoływania żydowskich kupców: „Pięć za złoty, kupujcie, kupujcie - malinowe”, po podwójnym torowisku turkotał tramwaj, po obu stronach jezdni stały szczelnie przylegające do siebie rzędy kamienic, klasycystyczna bryła szpitala ewangelickiego, dwie apteki, sklepiki, kawiarnie, cukiernie oraz liczne pracownie rzemieślników. Jacek Leociak z niezwykłą, detektywistyczną niemal precyzją tropi ślady po dawnych mieszkańcach ulicy, wyszukując w archiwalnych księgach adresowych ich imion, nazwisk i profesji: pod jedynką miał swój zakład krawiecki Herszko Berenholc, w kamienicy Karmelicka 3 zdejmowali miarę i szyli ubrania Moszek Feldman, Icchok Skórnik oraz Terca Zalcman, pod numerem 24 naprawiał futra Jesil Kumcher, pod 26 usadowił się kolejny kuśnierz Izrael Sztejnzalc i mieściły się dwie pracownie kapeluszy - pierwsza prowadzona przez Abrama Ajnsztajna, druga przez Eliasza Włodawera...

Dzięki zabiegom Leociaka polegającym na przywoływaniu nazwisk, przytaczaniu fragmentów opowieści dawnych mieszkańców i pokazywaniu czarno-białych fotografii niektóre miejsca dawnej Warszawy ożywają. „Ambicją tej książki jest pomoc w nauce patrzenia na to, co po getcie w krajobrazie współczesnej Warszawy pozostało” (Krochmalna, s. 4) - zaczynamy też, jak przewidywał autor, lepiej zauważać zachowane ślady przeszłości w przestrzeni miasta a także dostrzegać zabiegi wkładane w upamiętnianie historii (między innymi zaznaczone granice getta na płytach chodnikowych czy wytyczony w 1988 r. w okolicy Stawek Trakt Pamięci, Męczeństwa i Walki Żydów). Archeologia miejska, jaką uprawia Leociak, przez samą swoją tematykę jest jednak ciężka. Trudno się beztrosko cieszyć z jego odkryć, tak jak możemy się radować z odkrycia liczącej 4,3 tys. lat piramidy na pustyni w Sakkarze, znalezienia datowanych na 1010 r. przedmiotów ze srebra w okolicach Iławy czy wykopania szczątków „polskiego” neandertalczyka w jaskini Staj- 
nia. Radość z odkryć archeologicznych bierze się bowiem z przeświadczenia, że naturalny upływ czasu choć mógł, to nie zniszczył ich bezpowrotnie. Odkryciami Leociaka trudno się beztrosko cieszyć, gdyż odnalezione przez niego postaci czy przedmioty według prawa natury mogłyby istnieć, ale zostały świadomie zgładzone i zniszczone. Destrukcję i zniszczenia Muranowa dodatkowo podkreślają zamieszczone w książce współczesne zdjęcia tej okolicy autorstwa Macieja Jeziorka. Lekturze książki bezustannie towarzyszy więc ponura świadomość, że to, co zostało wydobyte, jeszcze intensywniej pokazuje to, czego nie ma. Wszystkie odnalezione ślady prowadzą nas do ludzi, którzy tu kiedyś żyli, a później umierali w getcie.

Czym różni się książka Jacka Leociaka od innych wydawnictw poświęconych gettu warszawskiemu? Przez ostatnie lata wyraźnie wzrósł asortyment narzędzi, dzięki którym możemy dowiadywać się o dwudziestowiecznej historii Warszawy, szczególnie o losach jej żydowskich mieszkańców. Niezwykle ważną, najbardziej wnikliwą i najszerszą próbę opowieści o „nieistniejącym mieście” podjęli w $2001 \mathrm{r}$. Barbara Engelking i Jacek Leociak ${ }^{1}$. Sześć lat później wydał swoją książkę o ulicy Chłodnej, w czasie wojny przemianowanej na Eisgrubenstrasse, Igor Piotrowski². Ewa Małkowska-Bieniek zaproponowała w opublikowanym w 2008 r. przewodniku kilka tras wędrówek śladami warszawskich Żydów po Pradze, Woli i Śródmieściu³. Jan Jagielski zgromadził fotografie przedstawiające materialne ślady byłego getta - fragmenty ulic, budynków, podwórek z tamtego czasu zachowane do dziśs . Jerzy S. Majewski, varsavianista popularyzujący wiedzę o stolicy na łamach „Gazety Wyborczej”, sporo miejsca poświęca opowieści o jej niegdysiejszych żydowskich mieszkańcach. Spojrzenia na warszawskie getto są kolejną propozycją miejskiej archeologii. To w moim odczuciu najbardziej osobisty, pisany niezwykle empatycznym językiem esej historyczny. To także książka, w której zaistnieli dawni mieszkańcy Warszawy - cytaty z ich zapisków i wypowiedzi obszernie powplatane w tekst Spojrzeń... tworzą barwny wielogłos moderowany przez Leociaka i uzupełniany jego komentarzami.

Marta Pietrzykowska

${ }^{1}$ Barbara Engelking, Jacek Leociak, Getto warszawskie. Przewodnik po nieistniejącym mieście, Warszawa: Wydawnictwo IFiS PAN, 2001.

${ }^{2}$ Igor Piotrowski, Chłodna. Wielkość i zapomnienie warszawskiej ulicy w świetle literatury pięknej, wspomnień i fotografii..., Warszawa: Mazowieckie Centrum Kultury i Sztuki i Wydawnictwo Trio, 2007.

${ }^{3}$ Ewa Małkowska-Bieniek, Śladami warszawskich Żydów, Warszawa: Urząd m.st. Warszawy, 2008.

${ }^{4}$ Jan Jagielski, Niezatarte ślady getta warszawskiego, Warszawa: Mówią Wieki, 2008. 